\title{
Spin-Offs and Their Impact on Shareholder Wealth: An Empirical Analysis on the German Capital Market
}

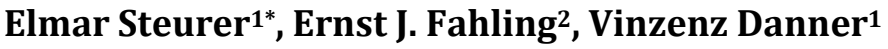 \\ ${ }^{1}$ Hochschule Neu-Ulm, Neu-Ulm, Germany \\ ${ }^{2}$ International School of Management, Frankfurt am Main, Germany \\ Email: *elmar.steurer@hnu.de
}

How to cite this paper: Steurer, E., Fahling, E. J., \& Danner, V. (2021). Spin-Offs and Their Impact on Shareholder Wealth: An Empirical Analysis on the German Capital Market. Journal of Financial Risk Management, 10, 397-415.

https://doi.org/10.4236/jfrm.2021.104022

Received: August 30, 2021

Accepted: October 26, 2021

Published: October 29, 2021

Copyright (C) 2021 by author(s) and Scientific Research Publishing Inc. This work is licensed under the Creative Commons Attribution International License (CC BY 4.0).

http://creativecommons.org/licenses/by/4.0/

\begin{abstract}
A parent company occasionally spin-off a subsidiary or a business unit if this helps to focus on the core business, eliminate a poor performer or reduce negative synergies in order to improve operational efficiency. Achieving a more efficient valuation on the capital market can also be a motive for a spin-off. The assumption is thus that spin-offs increase shareholder wealth. Despite the high relevance of spin-offs as a restructuring measure, empirical research has not yet sufficiently addressed this topic. The reasons for this are, on the one hand, the lack of topicality of publications and, on the other hand, the lack of consideration of the value effects of spin-offs in the European and, in particular, the German economic area. Accordingly, there is currently no adequate literature covering spin-offs in Germany. As a result, this paper addresses this problem by conducting an analysis of spin-offs in Germany. Consequently, this paper examines wealth effects for a sample of 8 spin-offs from Germany announced between January 2010 and February 2021. The cumulative average abnormal return over the three-day event window $[1 ;+1]$ is $4.91 \%$.
\end{abstract}

\section{Keywords}

Spin-Off, Germany, Shareholder Wealth

\section{Introduction}

For a long time, companies around the world pursued a diversification strategy (Charifzadeh, 2002: p. 1). Promising business areas were acquired in the course of mergers and acquisitions or built up by the company itself. The assumption was that existing expertise and management knowledge could be transferred to 
other industries without any difficulties, thus opening up new business areas and reducing the overall risk of the company. Ultimately, this should lead to an increase in the value of the company (Achleitner et al., 2003: p. 432). These considerations resulted in the emergence of large conglomerates. Accordingly, the prime focus was on the M\&A strategy (Charifzadeh, 2002: p. 1).

A major problem of these emerged conglomerates is their high complexity. This complexity arises primarily from broad diversification and the associated challenge of effectively managing all business units (Interview with Alexander Reimann, 2021). As a logical consequence, this is accompanied by high costs for maintaining control and transparency. A look at the capital markets shows that this causes a significant discount in the valuation of conglomerates. The valuation of a diversified company is therefore lower than the sum of its parts. According to Grane/Persson, this discount for conglomerates, along with management's overall goal of maximizing shareholder wealth, can be a motive for restructuring the company (Grane and Persson, 2018: p. 6).

One way to restructure a company is through a spin-off (Interview with Alexander Reimann, 2021). A spin-off is the pro-rata issue of shares of the company to be spun-off to the shareholders of the parent company (Slovin et al., 1995: p. 91). Apart from transaction costs, the issue is free of charge. The shareholders of the parent company thus own shares of two companies instead of one. They own both the shares of the parent company and the new shares of the spun-off subsidiary (Blanton et al., 2000: p. 8). In a first step, therefore, the ownership structure remains the same (Hite and Owers, 1986: p. 423). Furthermore, in a spin-off, neither the parent company nor the subsidiary receives any cash from the transaction (Achleitner, 2002: p. 362). In many cases, the spin-off is carried out at $100 \%$ of the shares, with the result that the parent company no longer has any control of the former subsidiary (Blanton et al., 2000: p. 8). After the transaction, the spun-off company operates independently in the market and has its own corporate bodies, administration, and reporting (Charifzadeh, 2002: p. 96). As a rule, after the shares have been transferred to the shareholders, they are admitted to stock exchange trading in a second step (Achleitner, 2002: p. 363). As Figure 1 illustrates, in the initial situation the shareholders only hold shares of the parent company. When the transaction is executed, the shares of the subsidiary are then distributed on a pro-rata basis to the previous shareholders of the parent company. The result is two companies with an identical group of shareholders.

With a spin-off of previously acquired or self-established business units, companies reduce their degree of diversification, and the focus on the activities remaining in the parent company can be increased (Achleitner et al., 2003: pp. 432-433). By separating the business units, the market receives more detailed information about the individual parts of the company and thus about potential profit opportunities. This more detailed information would not be available to investors in the group (Mazur, 2015: p. 127). As a consequence, there often is an increase in the enterprise value (Tagesschau, 2021). 

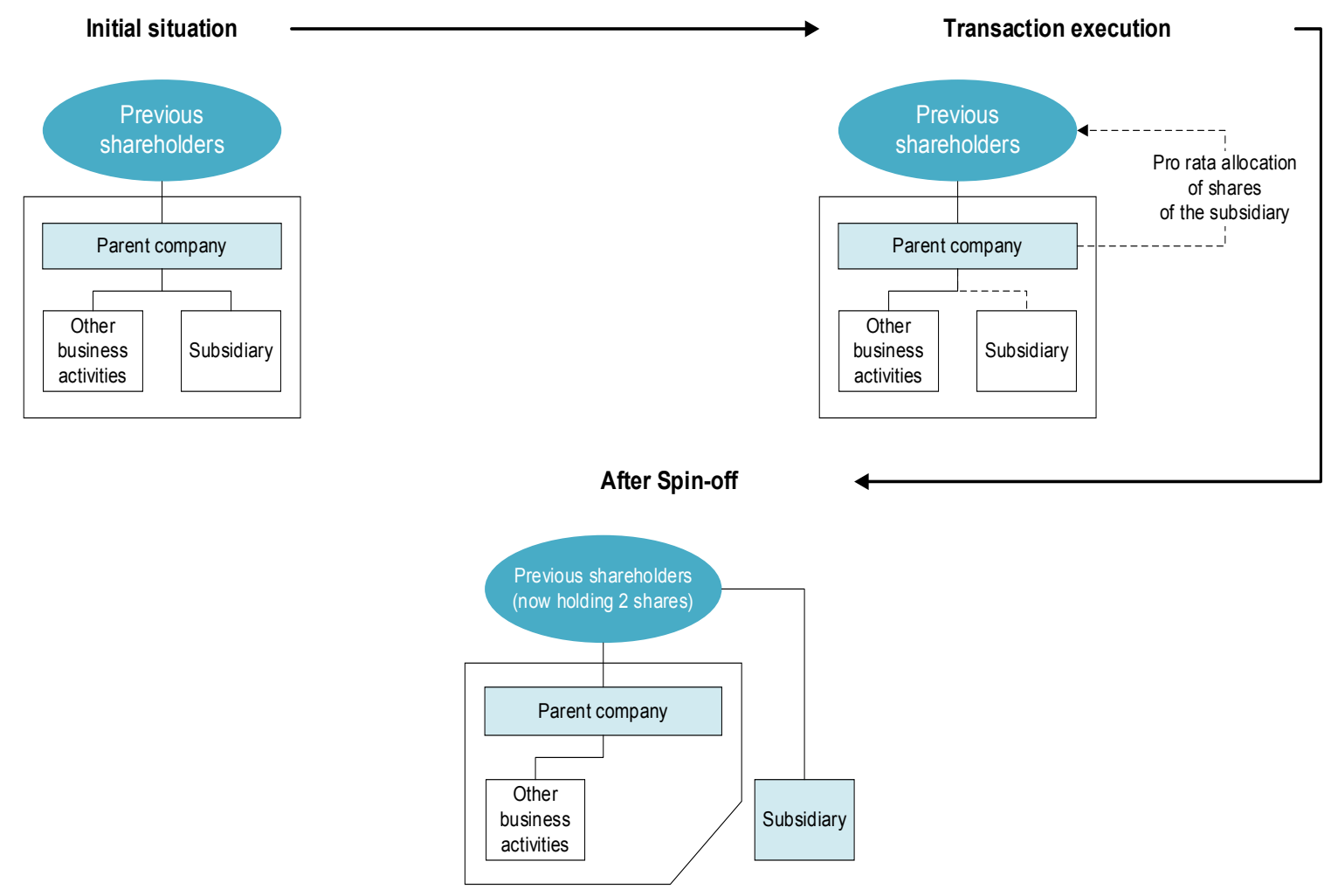

Figure 1. Spin-off. Source: Adapted from Charifzadeh (2002: p. 97).

Despite the increasing overall relevance of spin-offs as a corporate restructuring measure, empirical research has not sufficiently addressed this subject yet. The reasons for this are, on the one hand, the lack of topicality of the publications and, on the other hand, the lack of consideration of the value effects of spin-offs in the European and (Vollmar, 2014: p. 3) in particular in the German economic area (Ostrowski, 2008: p. 137) Vollmar's study, for example, focuses on European spin-off announcements, whereas Ostrowski generally examines the value effects of divestment measures in Germany. The value effects of spin-off announcements in Germany, which result from considerations regarding divestment and enterprise value enhancement methods, have not been analyzed so far. The existing evidence on the effects of spin-off announcements on enterprise value comes mainly from the USA (Uddin, 2010: p. 43). Hence, this paper deals with the value-oriented spin-off announcement of German company units and their impact on shareholder wealth.

This paper examines the value effect of 8 spin-off announcements that took place in Germany between 2010 and 2021. The results show that shareholders of the parent company gain approximately $4.91 \%$ in value after a spin-off announcement. The result is consistent with the argument that spin-offs have economic benefits that help increase shareholder wealth.

Section 2 provides an overview of the current state of research. The hypothesis stated, the research design, and the statistical testing methods used are described in Section 3. The results are presented and discussed in Section 4. Section 5 con- 
cludes with a summary.

\section{Literature Review}

Evidence shows that spin-off announcements create value for shareholders. For example, Hite \& Owers (1986), to cite just a few studies, examined 123 spin-off announcements for a period from 1961 to 1981 and found a significantly positive average abnormal return of $3.3 \%$ in the event window $[-1 ; 0]$. Rosenfeld (1984), to cite another study, examined 35 spin-off announcements for the period 1963 to 1981. He considered the period from -30 to +30 days around the event date and calculated the average abnormal returns and the cumulative average abnormal return. Moreover, he analyzed the returns for different time periods to closely examine the impact of the spin-off announcement on the parent company's stock prices. To improve comparability with the other spin-off studies, only the results for the event window around the event date are presented in Table 1. The excerpts from these two studies show that spin-off announcements have a positive effect on parent company stock prices. In contrast to Hite \& Owers (1986) and Rosenfeld (1984), Kumpfmüller (2018) did not examine U.S. spin-off announcements, but focused on European spin-off announcements. Kumpfmüller (2018) also examined the impact of voluntary corporate spin-off announcements on shareholder wealth. He also found a significant positive stock price reaction for European spin-offs for a sample of 101 spin-off announcements between 2000 and 2016.

In Table 1, we have presented some results of selected event studies dealing with short-term share price reactions of the spinning-off parent company around the announcement date of the spin-off. The time period of the publications covers the years 1983 to 2018, with the event studies based on stock prices from 1962 to 2016. The regional focus of the studies is on the Anglo-American region, as this can be seen as the origin for the application of event studies to the topic of spin-off. In addition, studies based on European data are also included. Ostrowski's own results are not included in the following table, as Ostrowski's study examines all available divestment measures and the results cannot be related specifically to spin-offs (Ostrowski, 2008: pp. 131-134).

\section{Ostrowski is not included in the following Table 1:}

The presented studies on the announcement effect of spin-offs exhibit significantly positive average abnormal returns in almost all event windows considered. The range of statistically significant abnormal returns is from $1.32 \%$ for an event window of 0 to +1 days to a maximum value of $5.56 \%$ for an event window of -1 to 0 days around the announcement date of the spin-offs. Accordingly, in all event windows presented, a positive abnormal return is generated regardless of the observed time period, geographic focus, sample size, and publication date of the empirical study. Although the majority of the studies refer to the U.S. capital market, no significant differences can be observed when looking at the studies related to Europe (Kumpfmüller, 2018: p. 45). 
Table 1. Research on spin-offs.

\begin{tabular}{|c|c|c|c|c|}
\hline Authors (Year) ${ }^{a}$ & Period $^{\mathrm{b}}$ & $\mathrm{N}^{\mathrm{c}}$ & Interval $^{\mathrm{d}}$ & CAAR $^{\mathrm{e}}$ \\
\hline Hite/Owers (1983) & 1963-1981 & 123 & {$[-1 ; 0]$} & $3.30 \% * * *$ \\
\hline Schipper/Smith (1983) & 1963-1981 & 93 & {$[-1 ; 0]$} & $2.84 \% * * *$ \\
\hline Miles/Rosenfeld (1983) & $1962-1980$ & 55 & {$[0 ;+1]$} & $3.34 \%^{* * *}$ \\
\hline Rosenfeld (1984) & $1963-1981$ & 35 & {$[-1 ; 0]$} & $5.56 \% * * *$ \\
\hline Allen/Lummer/McConnell/Reed (1995) & 1962-1991 & 94 & {$[-1 ; 0]$} & $2.15 \%^{* * *}$ \\
\hline Slovin/Sushka/Ferraro (1995) & $1980-1991$ & 37 & {$[0 ;+1]$} & $1.32 \%^{* *}$ \\
\hline Michaely/Shaw (1995) & $1981-1988$ & 9 & {$[-2 ;+2]$} & $4.46 \% *$ \\
\hline Seward/Walsh (1996) & $1972-1987$ & 78 & {$[-1 ;+1]$} & $2.60 \% * * *$ \\
\hline Johnson/Klein/Thibodeaux (1996) & $1975-1988$ & 104 & {$[-1 ; 0]$} & $3.96 \% * * *$ \\
\hline Daley/Mehrotra/Sivakumar (1997) & 1975-1991 & 85 & {$[-1 ; 0]$} & $3.40 \%^{* * *}$ \\
\hline Mulherin/Boone (2000) & 1990-1999 & 106 & {$[-1 ;+1]$} & $4.51 \%^{* * *}$ \\
\hline Chemmanur/Paeglis (2001) & $1991-2000$ & 19 & {$[-1 ; 0]$} & $4.45 \%^{* * *}$ \\
\hline Burch/Nanda (2003) & $1979-1996$ & 106 & {$[-1 ; 0]$} & $3.70^{\text {n.s. }}$ \\
\hline Veld/Veld-Merkoulova $(2004)^{*}$ & $1987-2000$ & 156 & {$[-1 ;+1]$} & $2.62 \% * * *$ \\
\hline Bühner $(2004)^{*}$ & $1991-2001$ & 39 & {$[-1 ;+1]$} & $2.27 \% * * *$ \\
\hline Rüdisüli $(2005)^{*}$ & $1990-2003$ & 189 & {$[-1 ;+1]$} & $2.80 \%^{* * *}$ \\
\hline McNeil/Moore (2005) & 1980-1996 & 153 & {$[-1 ;+1]$} & $3.53 \%^{* * *}$ \\
\hline Sudarsanam/Qian $(2007)^{\star}$ & $1987-2005$ & 157 & {$[-1 ;+1]$} & $4.82 \% * * *$ \\
\hline Vollmar $(2014)^{*}$ & $2000-2012$ & 83 & {$[-1 ;+1]$} & $4.58 \%^{* * *}$ \\
\hline Prezas/Simonyan (2015) & $1980-2011$ & 378 & {$[-1 ;+1]$} & $4.40 \% * * *$ \\
\hline Kumpfmüller $(2018)^{*}$ & $2000-2016$ & 101 & {$[-1 ;+1]$} & $3.23 \% * * *$ \\
\hline
\end{tabular}

${ }^{a}$ Authors and year of research $-{ }^{*}=$ European event study; ${ }^{b}$ Period in which the spin-offs were carried out; ' Number of spin-offs investigated; ${ }^{\mathrm{d}}$ Indicated are the periods of the most important intervals around the announcement date; ${ }^{e}$ Cumulative average abnormal return associated with the intervals- ${ }^{* *},{ }^{* *},{ }^{*}=$ significant at the $1 \%, 5 \%, 10 \%$ level; n.s. $=$ not specified; Source: Adapted from Ostrowski (2008: p. 134), and Kumpfmüller (2018: pp. 42-44).

\section{Research Method}

The success of the spin-off announcement is defined by its contribution to increasing shareholder wealth, measured by the market value of equity. One tool for assessing the change in enterprise value triggered by a spin-off announcement is the event study (Vollmar, 2014: p. 185). The event study represents one of the best-known procedures in empirical capital market research, which has established itself in the literature as a standard procedure for assessing announcement effects (Picken, 2003: p. 60).

The event study methodology measures the magnitude, direction, and speed of stock price reactions (Bowman, 1983: p. 562). Accordingly, it is assumed that the capital markets under investigation process information in observable stock 
prices. The theoretical framework of the event study is therefore based on the efficient market hypothesis (Vollmar, 2014: p. 187).

Therefore, in this paper, the semi-strong form of information efficiency applies, that is, share prices reflect all publicly available information in addition to historical prices (Fama, 1970: p. 388). The background for this is based on the fact that, in previous event studies, adjustments to new information were observable without a delay (Fama, 1991: pp. 1601-1602). Hence, the new information, which includes the announcement of a spin-off, leads to a reassessment of investor expectations and thus to a revaluation of the parent company (Vollmar, 2014: p. 188).

\subsection{Research Objective}

Even if the theoretical explanations of the value enhancement by spin-offs are based on partly different premises, a value-enhancing effect of spin-offs can be derived from these as well as from the studies presented, and the following hypothesis can be stated:

On average, the announcement of German spin-offs results in significant positive abnormal returns for the parent companies.

\subsection{Research Design}

In the beginning, the event to be examined must be defined. Accordingly, events in connection with the announcement of a spin-off by a German parent company are examined subsequently (Jahn, 2011: p. 5).

Conducting an event study places further requirements on the factual delimitation of events (McWilliams and Siegel, 1997: p. 634). For instance, the event must not be superimposed by other price-relevant facts that occur at the same time or are close in time. These are referred to as confounding events and include the publication of business figures and the announcement of dividends or other restructuring measures (Goerke, 2009: pp. 469-472). Without excluding these events, the measurement of abnormal returns would not be clearly attributable to the event under investigation. As a result, the significance of the results would also be severely limited (May, 1991: p. 321). Confounding events should therefore be excluded throughout the research period. Therefore, all sample elements that are exposed to such confounding events are eliminated (Goerke, 2009: p. 471).

Furthermore, the determination of the event time is of great importance (Bowman, 1983: p. 564). In the further course, the event time is therefore the first spin-off announcement of a German parent company. In this context, strict requirements have to be applied to the announcement dates used. Since existing information has already been processed in the share prices, the event time must be the day on which information that is entirely new to the capital market is published. The event must therefore not yet have been anticipated by capital market participants. This would otherwise lead to some market participants having already processed the information in their decisions (Campbell et al., 
1997: p. 151).

For determining the announcement date, there are generally three options. These are publication of the spin-off announcement in national media, special types of information announcement based on national regulations, such as ad-hoc announcements, and other public databases. While publications in national media and information announcements based on national regulations are usually more accurate, databases offer increased comparability and easier handling (Lenhard, 2009: p. 129). Due to this, a combination of these three options is used in the research (Vollmar, 2014: p. 191).

\subsubsection{Data Set and Research Sample}

The data quality depends on various factors, which are taken into account in the sampling. The basis for narrowing down the sample of spin-off announcements is the Mergers \& Acquisitions database of the data provider Refinitiv. Here, 5007 spin-off announcements are initially identified. In order to narrow down the sample, a multi-stage procedure is selected based on the delimitation criteria explained above (Vollmar, 2014: p. 192).

1) The information on share prices required in the context of event studies makes it necessary to initially narrow the scope of the investigation to listed companies (Vollmar, 2014: p. 192). This leads to a reduction of spin-off announcements to 4105 .

2) The sample is narrowed down to spin-off announcements made by corporations headquartered in the German economic area within the period of January 1, 2010 to February 28, 2021. This framework is chosen to, on the one hand, obtain findings that are as up to date as possible, and, on the other hand, to ensure the availability of the required data (Vollmar, 2014: p. 192). This step limits the number of spin-off announcements to 19 .

3) Furthermore, spin-off announcements by companies from the financial industry are excluded from the sample. This exclusion is due to the fact that finance companies have very specific company characteristics, which would lead to significant distortions in the empirical analysis (van Lelyveld and Knot, 2008: p. 3). Due to the fact that no financial company has carried out a spin-off in the last 10 years, 19 companies remain in the sample.

4) As mentioned above, the existence of a sufficient quantity and quality of data is the basic prerequisite for consistent research results. On the one hand, the temporal accuracy of the event data, which includes the stock price and the announcement date, is a critical success factor. On the other hand, checking for confounding events must not be neglected. For this purpose, the Refinitiv database is used again. The availability of share prices adjusted for corporate actions is checked (Goerke, 2009: pp. 467-470). Since simple closing prices take changes in equity into account but ignore dividend payments, the adjusted closing price is used. This adjusted closing price makes it possible to obtain the unaffected performance of the stock. Therefore, it is particularly useful when studying historical returns, as it provides an accurate representation of the company's stock 
value. If no information on the adjusted closing price is available, the sample element is excluded from the analysis (Ganti, 2020). Therefore, no company is excluded.

5) In addition to the adjustment of the share price, comprehensive preparation of the data set with regard to the announcement date is also necessary. The date to be considered in event studies refers to the time when the information is first disclosed to the capital market. Consequently, the date of the first publication about the spin-off project by the parent company is relevant (Vollmar, 2014: p. 194). Typically, these are announcements which, as part of the disclosure obligations, force the issuer of securities to immediately publish facts which may significantly influence the stock market price (Quentmeier, 2012: pp. 106-114). In order to increase the comparability of announcement dates, the announcement dates deposited in Refinitiv are initially applied. Subsequently, each sample element is compared with the mandatory announcements published by the company and corrected if necessary. This ensures that the day on which the spin-off announcement was made can be selected in each case. If the corresponding announcement date cannot be verified beyond doubt, the sample element is excluded from the investigation (Vollmar, 2014: p. 194). After this step, 13 elements remain.

6) In order to prevent confounding events from overlaying the announcement date and thus distorting the share price reactions to spin-off announcements, the remaining sample is checked for such events using the Refinitiv database. In addition, accessible press and media releases are also used and analyzed. If a price-sensitive event occurs within three days before and after the spin-off announcement, the sample element is excluded from the investigation (Vollmar, 2014: p. 195). This restricts the sample to 10 spin-off announcements.

7) For a consistent approach, it is necessary to verify that the spin-off announcements listed in the remaining sample are consistent with the definition presented in Section $[1$.

Pursuant to this definition, the spin-off must meet the following requirements:

- distribution of the shares of the subsidiary to be spun-off on a pro rata basis to the shareholders of the parent company (Slovin et al., 1995: p. 91);

- admission to stock exchange trading of the subsidiary being spun-off (Achleitner, 2002: p. 363).

Furthermore, it is important that the spin-off is voluntary (Vollmar, 2014: p. 195). Otherwise, the restructuring measure cannot be considered in terms of value enhancement (Achleitner, 2002: p. 370). The analysis of the sample according to the preceding criteria leads to a reduction of the sample size to 8 spin-off announcements.

The following Figure 2 summarizes the sampling for clarity.

\subsubsection{Abnormal Returns}

The valuation changes on the capital markets triggered by a spin-off announcement 


\begin{tabular}{lrr} 
Investigation step & Adjustment & Remaining \\
\hline Population & -902 & $\mathbf{5 0 0 7}$ \\
1. Listed & -4086 & 4105 \\
2. Germany & 0 & 19 \\
3. Not a financial company & 0 & 19 \\
4. Availability of share price information & -6 & 19 \\
5. Determinability of the announcement date & -3 & 13 \\
6. No confounding events & -2 & 10 \\
7. Conforms to definition & & 8 \\
\hline Total & & $\mathbf{8}$
\end{tabular}

Figure 2. Sampling. Source: Own compilation based on data from Refinitiv-Eikon.

are measured by using abnormal returns (Vollmar, 2014: p. 196). These reflect the information content of an event with regard to the value of the company (Brown and Warner, 1980: p. 205). Abnormal returns represent the difference between the return that occurred in the event period and the return that would have been expected without the event. Formally, this connection is defined as follows (Campbell et al., 1997: p. 151)

$$
A R_{i, t}=R_{i, t}-E\left(R_{i, t}\right)
$$

with

$A R_{i, t}$ : abnormal return of share $i$ at time $t$

$R_{i, t}:$ return of share $i$ at time $t$

$E\left(R_{i, t}\right)$ : expected return of share $i$ at time $t$

Based on this, the average abnormal returns of a study sample can be calculated as follows (Vollmar, 2014: p. 197):

$$
A A R_{t}=\frac{1}{N} \sum_{i=1}^{N} A R_{i, t}
$$

with

$A A R_{t}$ : average abnormal return of sample at time $t$

$A R_{i, t}$ : abnormal return of share $i$ at time $t$

$N$ : number of sample elements

The determination of abnormal returns requires a consideration regarding the type of return calculation (Fassnacht, 2011: pp. 94-97). In principle, continuous or simple returns can be used. Both alternatives have different advantages and disadvantages (Vollmar, 2014: p. 199). Continuous returns are based on the assumption of a continuous interest rate and are calculated using the natural logarithm. They have mainly statistical advantages, hence, many studies use them (Ostrowski, 2008: p. 198). First, they allow the financial mathematically correct summation of returns over time and the calculation of arithmetic means of returns. Cumulating over time can be done by adding the continuous returns, which is not the case for simple returns. In contrast, simple returns have the advantage of additivity along portfolios (Campbell et al., 1997: p. 11). In this case, portfolio returns can be calculated by adding up the securities contained in the portfolio. Continuous returns do not have this property. The simple addition of 
continuous returns would lead to a systematic underestimation of portfolio returns (Barber and Lyon, 1997: pp. 349-350). For this reason, simple returns are preferred in event studies. This can be formally represented as (Vollmar, 2014: p. 198):

$$
R_{i, t}=\frac{P_{i, s}-P_{i, s-1}}{P_{i, s-1}}=\frac{P_{i, s}}{P_{i, s-1}}-1
$$

with

$R_{i, t}$ : simple return of share $i$ in period $t(\triangleq s-1$ to $s)$

$P_{i, s}$ : share price $i$ adjusted for corporate actions and dividends at time $s$

$P_{i, s-1}$ : share price $i$ adjusted for corporate actions and dividends at time $s-1$

Besides the method for calculating returns, a decision must also be made regarding the maturity of returns. In principle, monthly, weekly, or daily returns can be used for this purpose (Ostrowski, 2008: p. 124). Due to the slightly higher informative value of daily returns compared to weekly and monthly returns, the use of daily returns is suggested for event studies (Bartsch, 2005: pp. 122-123). In addition, the use of daily returns is also useful in the context of semi-strong information efficiency, since price reactions can be expected within a few days around the announcement date (Ostrowski, 2008: p. 124). The use of daily data in event studies can be described as an international standard (Bartsch, 2005: p. 123). Since announcements of divestments can be determined to the day, the use of daily returns has also become established in event studies on divestments in the German capital market (Ostrowski, 2008: p. 124). Based on the preceding argumentation, daily returns are used in this event study.

\subsubsection{Expected Returns}

The calculation of abnormal returns in event studies requires an estimate of the returns that would have been expected in the absence of the occurrence of the event. These expected returns can be determined using pricing models (MacKinlay, 1997: p. 17).

The model most commonly used for event studies is the market model (Strong, 1992: p. 537). The market model assumes a linear relationship between the stock return of a company and the return of a market portfolio. Formally, the market model is represented as follows (MacKinlay, 1997: p. 18):

$$
E\left[R_{i, t}\right]=\alpha_{i}+\beta_{i} E\left[R_{m, t}\right]+\epsilon_{i, t}
$$

with

$E\left[R_{i, t}\right]:$ expected return of share $i$ at time $t$

$E\left[R_{m, t}\right]$ : expected return of market portfolio

$\alpha_{i}$ : return component of stock $i$ independently of market return

$\beta_{i}$ : return sensitivity of share $i$ in relation to market return

$\epsilon_{i, t}$ : error term

Thereby applies

$$
E\left[\epsilon_{i, t}\right]=0 \text { and } \operatorname{Var}\left(\int_{i, t}\right)=\sigma_{\epsilon_{i}}^{2}
$$


The expected returns calculated using the market model are referred to as market-adjusted and risk-adjusted (Brown and Warner, 1980: p. 234). In order for the market model to be applied, regression parameters must be estimated. For this purpose, an estimation period must be determined in advance of the event (Ostrowski, 2008: p. 123). This estimation period typically immediately precedes the event period in which the response is measured. The separation between the estimation period and the event period is to prevent the event from affecting the estimation of the parameters. This is to allow the market model to model the normal return that would have been expected if the event had not occurred (Picken, 2003: p. 96).

The market adjusted return model is considered a special case of the market model. In this special case, the following values apply to the regression parameters of the market model: $\alpha_{i}=0$ and $\beta_{i}=1$. Formally, the expected return is thus obtained as follows (Ostrowski, 2008: pp. 123-124):

$$
E\left[R_{i, t}\right]=E\left[R_{m, t}\right]+\epsilon_{i, t}
$$

with

$E\left[R_{i, t}\right]:$ expected return of share $i$ at time

$E\left[R_{m, t}\right]:$ expected return of market portfolio

$\epsilon_{i, t}:$ error term

Thereby applies

$$
E\left[\epsilon_{i, t}\right]=0 \text { and } \operatorname{Var}\left(\int_{i, t}\right)=\sigma_{\epsilon_{i}}^{2}
$$

In the model of market adjusted returns, the expected return of a security under consideration therefore corresponds to the return of the market portfolio. Thus, no estimation period is required to determine the abnormal returns (Vollmar, 2014: p. 204).

Despite the fact that the choice of pricing model plays a significant role, there is no conclusive agreement in literature concerning which model is most suitable for conducting event studies (Fassnacht, 2011: p. 108). Therefore, the market adjusted return model is used to determine the expected return. Simulation studies have indicated that there are no significant differences in terms of accurately capturing the abnormal return while using the different models (Brown and Warner, 1980: p. 216). Further research on the impact of different market sentiments on the market model results and the results of pricing models with mean adjustment and with market adjustment conclude that there are no differences in results when the event period is two trading days. However, by extending the event period by several days, the cumulative abnormal returns show misspecification if the mean adjusted returns are used. In contrast, the market adjusted returns and the returns that result when the market model is used are correctly specified (Klein and Rosenfeld, 1987: pp. 345-349).

Studies on the validity of the market model for the German capital market arrive at diverging results (Möller, 1985: pp. 509-510). Even if it is criticized that the market model is not able to provide a complete description of price forma- 
tion on the stock market, the use of the special case of this method seems to be justified. None of the methods developed and used so far is suitable to represent reality without deficiencies (Ostrowski, 2008: p. 196). Compared to the market model, the special case of market adjusted returns has the advantage that the problem of confounding events in long estimation periods can be addressed (Röder, 1999: p. 31).

With the choice of market-adjusted returns as the pricing model, a decision regarding the length of an estimation period is no longer necessary (Ostrowski, 2008: p. 196). Nonetheless, an event period must also be determined for market-adjusted returns. The event period covers the time period in which an event is assumed to have an impact on the share price. Accordingly, the abnormal returns are determined in this event window (Vollmar, 2014: p. 207). There are no specifications for the length of the event window. However, the decision for the time period should be based on a careful consideration of the associated advantages and disadvantages (Peterson, 1989: p. 38). Long periods offer the advantage that all abnormal price reactions can be captured. This is due to the price reactions observable in advance of the events, which can possibly be attributed to insider trading. If event periods are comparatively long, such price swings are reflected. In contrast, long event periods contradict the underlying hypothesis of information efficiency of the markets (McWilliams and Siegel, 1997: p. 630). In addition, the choice of long event periods raises the problem of confounding events. By using a short event period, the number of such events can be reduced. The longer the period, the more likely it is that further information with the potential to influence the share price will become known (Ostrowski, 2008: p. 196).

Regarding the length of the event window, this paper follows previous research on divestments to ensure comparability of results. The intervals considered are $[-20 ; 0],[10 ; 0],[-5 ; 0],[-2 ; 0],[-1 ; 0],\{0\},[-1 ;+1],[-2 ;+2],[-5$; $+5]$, $[-10 ;+10]$, and $[-20 ;+20]$ (Stienemann, 2003: pp. 180-185). Nevertheless, the focus is on the $[-1 ;+1]$ interval, which, in literature, is considered sufficient to measure abnormal returns (MacKinlay, 1997: p. 35). Trading-free days are not considered in the research and are excluded (Vollmar, 2014: p. 207).

A benchmark index is also required to calculate the expected returns (Bühner, 2004: p. 130). For this purpose, this paper uses the capital-weighted Composite DAX (CDAX) in its form as a performance index.

\subsubsection{Return Aggregation}

In order to capture the economic value effects of an event on a company's share price in its entirety, the abnormal returns in event studies are aggregated over time across different intervals. When examining announcement effects, cumulative abnormal returns are calculated for this purpose. Formally, the cumulative abnormal return can be modeled as follows (Fassnacht, 2011: pp. 101-102):

$$
C A R_{i, t_{1}-t_{2}}=\sum_{t=t_{1}}^{t_{2}} A R_{i, t}
$$

with 
$C A R_{i, t_{1}-t_{2}}$ : cumulative abnormal return of share $i$ in event window $\left[t_{1} ; t_{2}\right]$

$A R_{i, t}$ : abnormal return of share $i$ at time $t$

To determine the value effects of all spin-off announcements included in the examination, the cumulative abnormal returns are also aggregated across the sample. The resulting cumulative average abnormal return aggregates the total effect measured within the event window (MacKinlay, 1997: p. 24):

$$
C A A R_{t_{1}-t_{2}}=\frac{1}{N} \sum_{i=1}^{N} C A R_{i, t_{1}-t_{2}}
$$

with

$C A A R_{t_{1}-t_{2}}$ : cumulative average abnormal return in event window $\left[t_{1} ; t_{2}\right]$

$C A R_{i, t_{1}-t_{2}}$ : cumulative abnormal return of share $i$ in event window $\left[t_{1} ; t_{2}\right]$

$N$ : number of sample elements.

\subsection{Statistical Testing}

Various significance tests can be considered for the investigation of abnormal returns. Basically, a distinction is made between parametric and non-parametric test methods. While the parametric methods are based on distribution assumptions, the non-parametric tests do not require any assumptions about the distribution (Ostrowski, 2008: pp. 127-128).

The parametric test methods are usually based on the assumption that the abnormal returns of each firm are normally distributed (Serra, 2002: p. 4). The most common parametric test procedure used in event studies to analyze abnormal returns is the one-sample t-test (Ostrowski, 2008: p. 127). Due to this high relevance, the one-sample t-test is also used in this paper.

On the one hand, the t-test assumes a normal distribution of the data, which is regularly not the case in reality. On the other hand, a sufficiently large sample is required for the t-test. In the context of event studies, it therefore makes sense to use non-parametric test methods in addition to the parametric test methods (Kumpfmüller, 2018: p. 63).

The Wilcoxon signed-rank test is one of the best known non-parametric test methods (Vollmar, 2014: p. 218). For this test, there are no specific assumptions to be made regarding the underlying distribution of returns. The method is not based on the mean, but on the median of the abnormal returns. Thus, the distribution of the returns is negligible (Kumpfmüller, 2018: pp. 63-64).

Based on the above considerations regarding the distribution of the returns and the given sample size, the parametric method alone is not robust enough. Therefore, to verify the significance results of the one-sample t-test, the Wilcoxon signed-rank test is used additionally.

\section{Research Results}

In order to verify the stated hypothesis, all elements of the sample were examined using the event study methodology described above. Table 2 shows the results of the investigation for the entire sample. 
Table 2. Results of the event study for CAAR.

\begin{tabular}{|c|c|c|c|c|c|c|c|c|c|c|c|}
\hline & \multicolumn{11}{|c|}{ Event windows } \\
\hline & {$[-20 ; 0]$} & {$[-10 ; 0]$} & {$[-5 ; 0]$} & {$[-2 ; 0]$} & {$[-1 ; 0]$} & $\{0\}$ & {$[-1 ;+1]$} & {$[-2 ;+2]$} & {$[-5 ;+5]$} & {$[-10 ;+10]$} & {$[-20 ;+20]$} \\
\hline $\mathrm{N}$ & 8 & 8 & 8 & 8 & 8 & 8 & 8 & 8 & 8 & 8 & 8 \\
\hline Min & $-7.65 \%$ & $-4.53 \%$ & $-1.18 \%$ & $-0.23 \%$ & $0.21 \%$ & $0.35 \%$ & $-1.49 \%$ & $0.03 \%$ & $-2.47 \%$ & $-9.00 \%$ & $-5.47 \%$ \\
\hline $\operatorname{Max}$ & $14.73 \%$ & $12.59 \%$ & $9.56 \%$ & $9.21 \%$ & $8.81 \%$ & $10.59 \%$ & $10.46 \%$ & $10.70 \%$ & $9.95 \%$ & $21.24 \%$ & $23.34 \%$ \\
\hline SD & $7.47 \%$ & $6.39 \%$ & $3.78 \%$ & $3.74 \%$ & $3.59 \%$ & $3.80 \%$ & $4.88 \%$ & $4.73 \%$ & $5.00 \%$ & $9.72 \%$ & $11.38 \%$ \\
\hline Median & $8.71 \%$ & $6.20 \%$ & $5.36 \%$ & $3.49 \%$ & $3.84 \%$ & $4.06 \%$ & $5.23 \%$ & $2.12 \%$ & $8.07 \%$ & $10.59 \%$ & $8.86 \%$ \\
\hline$\%>0$ & $87.50 \%$ & $75.00 \%$ & $87.50 \%$ & $87.50 \%$ & $100.00 \%$ & $100.00 \%$ & $75.00 \%$ & $100.00 \%$ & $75.00 \%$ & $75.00 \%$ & $75.00 \%$ \\
\hline CAAR & $7.08 \%$ & $5.28 \%$ & $5.00 \%$ & $4.12 \%$ & $4.17 \%$ & $4.57 \%$ & $4.91 \%$ & $4.60 \%$ & $5.58 \%$ & $8.60 \%$ & $9.45 \%$ \\
\hline \multirow[t]{2}{*}{$\begin{array}{l}\text { One Sample t-Test } \\
\text { t-Value }\end{array}$} & 2.68 & 2.34 & 3.74 & 3.11 & 3.29 & 3.41 & 2.85 & 2.75 & 3.16 & 2.50 & 2.35 \\
\hline & $* *$ & $* *$ & $* * *$ & $* * *$ & $* * *$ & $* * *$ & $* *$ & $* *$ & $* * *$ & $* *$ & $* *$ \\
\hline \multirow[t]{2}{*}{$\begin{array}{l}\text { Wilcoxon-Signed- } \\
\text { Rank-Test T-Value }\end{array}$} & 4 & 5 & 1 & 1 & 0 & 0 & 4 & 0 & 3 & 3 & 6 \\
\hline & $* *$ & ** & $* * *$ & $* * *$ & $* * *$ & $* * *$ & ** & $* * *$ & ** & ** & * \\
\hline
\end{tabular}

$\mathrm{N}$ corresponds to the sample size; Min, Max, SD and Median show the minimum, maximum, standard deviation and the median of the cumulative abnormal returns in the event window; $\%>0$ represents the proportion of positive cumulative abnormal returns; CAAR corresponds to the cumulative average abnormal return in the event window; t-value calculated from the One Sample t-Test; T-value calculated from the Wilcoxon-Signed-Rank-Test; ${ }^{*},{ }^{* *}$, and ${ }^{* * *}$ represent the $10 \%, 5 \%$, and $1 \%$ significance levels.

Evidence shows that, on average, the announcement of a spin-off is accompanied by significantly positive abnormal stock price reactions. In the event window $[-1 ;+1]$, cumulative average abnormal returns of $4.91 \%$ can be found. Significant positive price responses can also be observed in all other event windows considered, ranging from $4.12 \%$ to $9.45 \%$.

For all event windows considered, the chosen parametric test method shows that the results are significantly different from zero in terms of CAAR. In the event windows $[-20 ; 0],[-10 ; 0],[-1 ;+1],[-2 ;+2],[-10 ;+10]$, and $[-20$; +20 ], the significance level is $5 \%$, in all other event windows it is $1 \%$. The non-parametric Wilcoxon signed-rank test confirms the results of the parametric test method.

Table 3 displays the results for the average abnormal returns of each day in the interval $[-10 ;+10]$. It can be seen that the highest abnormal price responses can be measured on the event day. The results are statistically significantly different from zero at the $1 \%$ level. This is confirmed by both the parametric one-sample t-test and the non-parametric Wilcoxon signed-rank test.

The magnitude of the abnormal returns on each day during the interval $[-20$; +20 ], shown in Figure 3, illustrates the significant stock price reaction on the event day.

Figure 4 shows the CAAR over time through the event window $[-20 ;+20]$. 


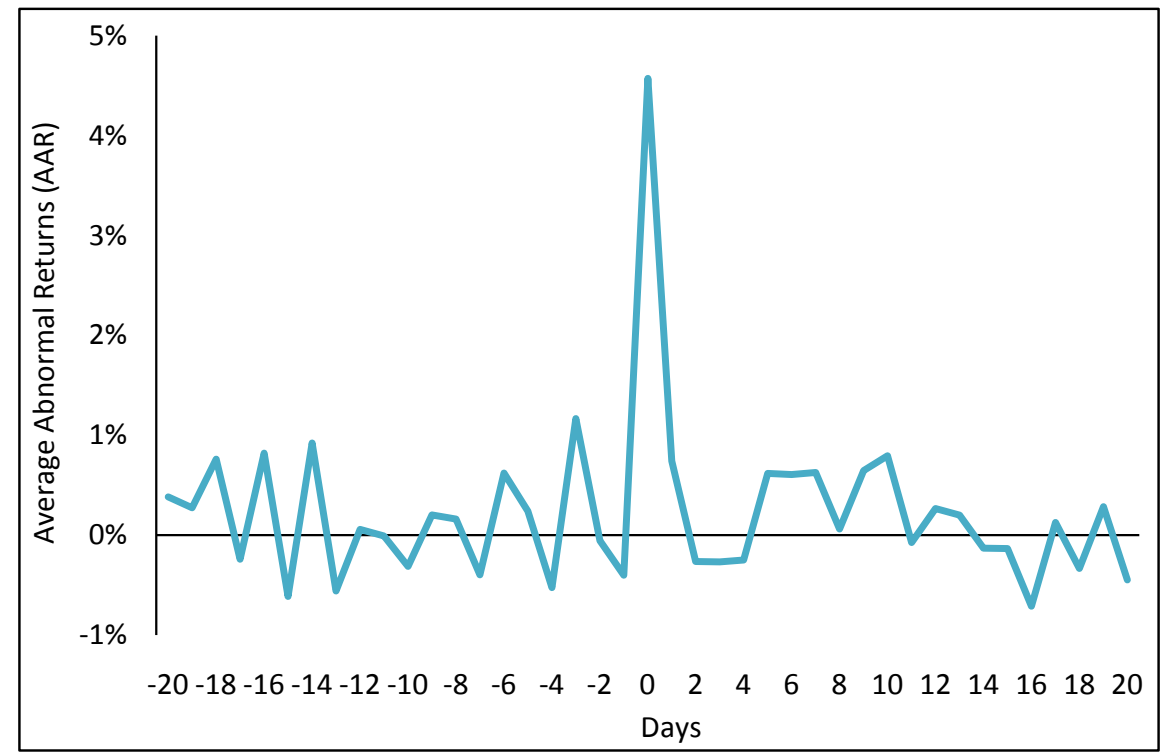

Figure 3. ARR in the interval $[-20 ;+20]$.

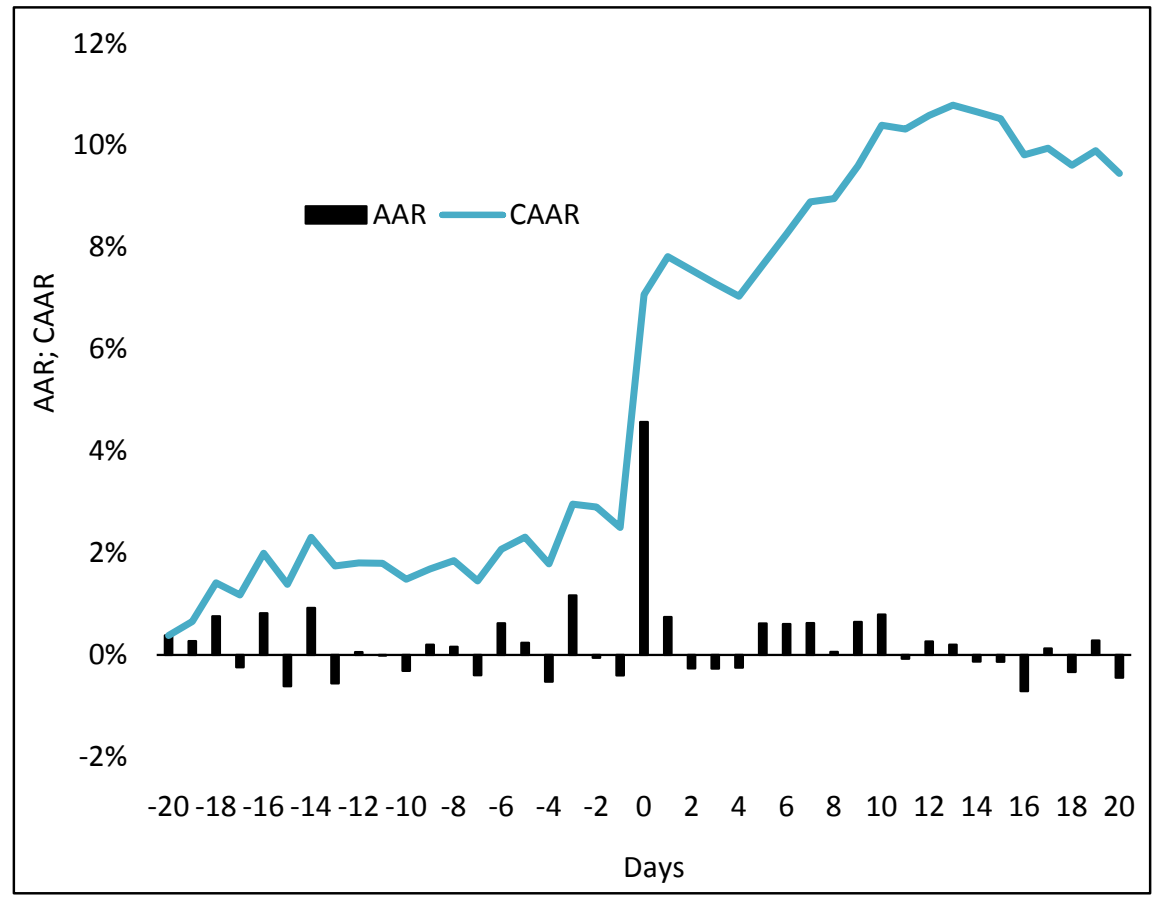

Figure 4. ARR and CAAR over the interval $[-20 ;+20]$.

Table 3. Results of the event study for AAR.

\begin{tabular}{|c|c|c|c|c|c|c|c|c|c|c|c|}
\hline Day & $\mathrm{N}$ & Min & $\operatorname{Max}$ & SD & Median & $\%>0$ & AAR & $\begin{array}{c}\text { One Sample } \\
\text { t-Test } \\
\text { t-Value }\end{array}$ & & $\begin{array}{c}\text { Wilcoxon-Signed- } \\
\text { Rank-Test } \\
\text { T-Value }\end{array}$ & \\
\hline-10 & 8 & $-6.79 \%$ & $2.71 \%$ & $3.12 \%$ & $-0.08 \%$ & $50.00 \%$ & $-0.31 \%$ & -0.28 & n.s. & 17 & n.s. \\
\hline-9 & 8 & $-1.41 \%$ & $4.74 \%$ & $2.00 \%$ & $-0.55 \%$ & $25.00 \%$ & $0.20 \%$ & 0.29 & n.s. & 14 & n.s. \\
\hline-8 & 8 & $-2.27 \%$ & $1.86 \%$ & $1.32 \%$ & $0.40 \%$ & $62.50 \%$ & $0.16 \%$ & 0.35 & n.s. & 15 & n.s. \\
\hline
\end{tabular}




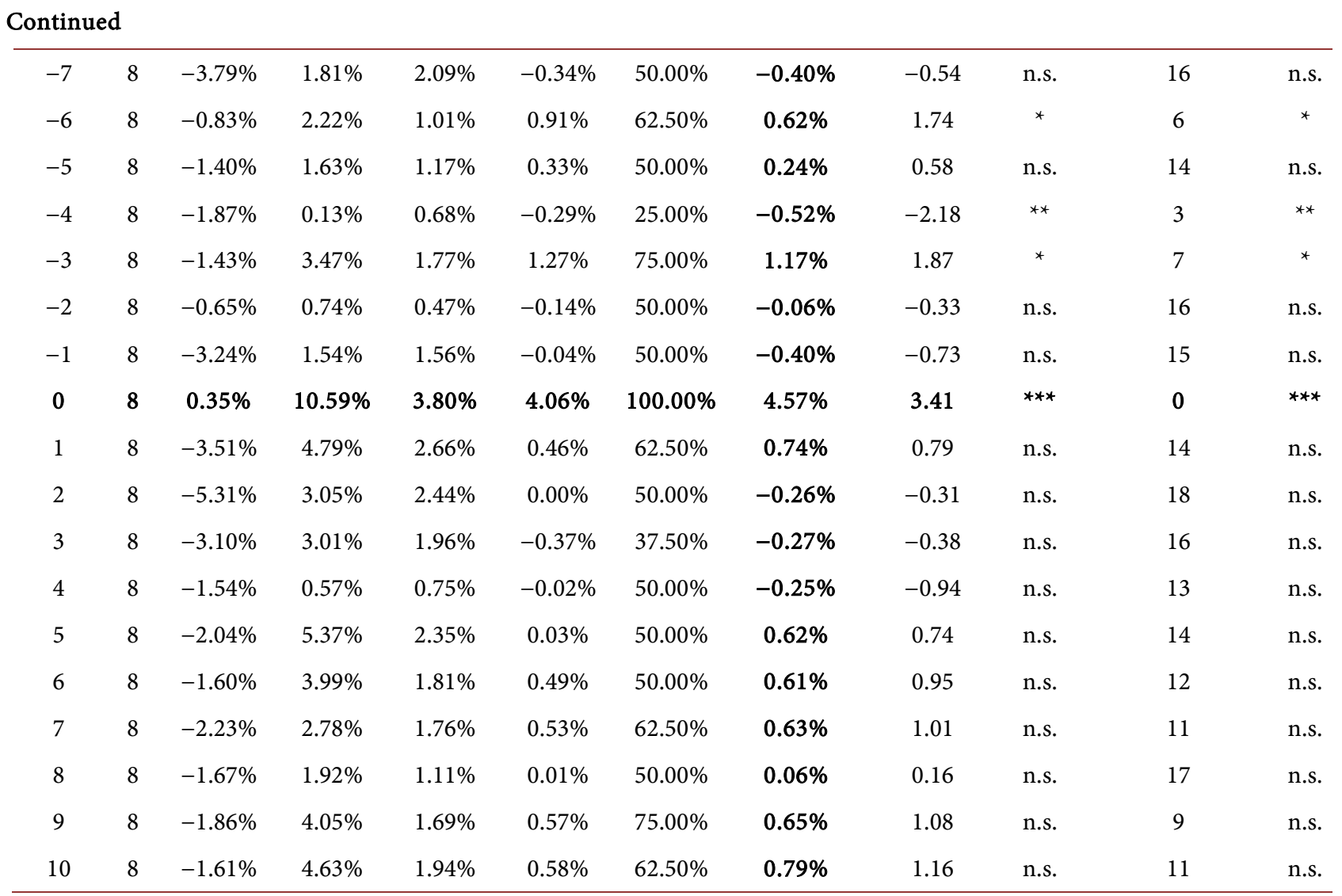

Day refers to the unified days starting with the spin-off announcement; $\mathrm{N}$ corresponds to the sample size; Min, Max, SD and Median show the minimum, maximum, standard deviation and the median of the cumulative abnormal returns in the event window; $\%>0$ represents the proportion of positive cumulative abnormal returns; AAR represents the average abnormal returns of the research sample; $\mathrm{t}$-value calculated from the One Sample t-Test; T-value calculated from the Wilcoxon-Signed-Rank-Test; ${ }^{*}$, ${ }^{\star *}$, and ${ }^{\star * *}$ represent the $10 \%, 5 \%$, and $1 \%$ significance levels; n.s. represents non-significant results.

The abnormal stock returns behave negatively on the two days before the announcement of the spin-off. However, these abnormal returns are not statistically significant. In contrast, a significant positive abnormal return is observed three days prior to the announcement. Based on these results, it can also not be proven beyond doubt that stock prices in the run-up to the spin-off announcement systematically contain information about the upcoming event, and thus insider trading is present.

Moreover, the CAAR increases up to $9.45 \%$ after the event day. European studies on spin-off announcements come to different results for this interval. In these, a declining CAAR is measured in the 20 days after the spin-off announcement (Vollmar, 2014: pp. 240-241). This suggests that the German stock market is very receptive to spin-offs. In addition, it can be concluded that listed companies in Germany achieve a sustainable increase in value through spin-offs, and the focus strategy of German companies is rewarded by investors.

The stated hypothesis cannot be rejected based on the results of the event study. The parent companies generate short-term positive and statistically significant abnormal returns across all event windows. Consequently, the German 
capital market reacts information-efficiently to the announcement of spin-offs, as the processing of the new information takes place within a few days in the share prices.

\section{Summary}

The research has shown that German spin-off announcements are price-relevant information that creates enterprise value. Using the market adjusted return model, a statistically significant cumulative average abnormal return of $4.91 \%$ in the event window $[-1 ;+1]$ can be obtained.

The results also indicate that German spin-offs, beyond the announcement, are very positively received by the capital markets. This is expressed by the fact that the CAAR continues to increase strongly when examining the medium-term event window $[-20 ;+20]$. In this event window, the statistically significant $\mathrm{cu}-$ mulative average abnormal return is $9.45 \%$. In addition, the significant average abnormal return of $4.57 \%$ on event day [0] is also very notable. On this day, all eight investigated companies show a positive return. Moreover, this also shows, compared to the event window $[-1 ;+1]$, that the majority of the stock price reactions occur on the event day [0].

The core question of the paper, whether German spin-off announcements have a positive impact on shareholder wealth, can be answered in the affirmative based on the research conducted and the theoretical explanations for the increase in value presented.

The identified positive impact of spin-off announcements on returns could motivate German corporations to use spin-off strategies more extensively to create shareholder wealth instead of focusing on M\&A strategies.

\section{Appendix}

Table presenting the descriptive statistics of main variables.

\begin{tabular}{ccccccccc}
\hline$[t 1 ; t 2]$ & Company 1 & Company2 & Company3 & Company4 & Company 5 & Company6 & Company7 & Company 8 \\
\hline$[-20 ; 0]$ & 0.100887 & 0.044325 & 0.073299 & -0.076530 & 0.128941 & 0.130877 & 0.016947 & 0.147258 \\
{$[-10 ; 0]$} & 0.111985 & -0.045274 & 0.040814 & 0.027186 & 0.125850 & 0.083140 & -0.024027 & 0.102429 \\
{$[-5 ; 0]$} & 0.067668 & 0.027036 & 0.039463 & 0.018653 & 0.095638 & 0.072486 & -0.011810 & 0.090875 \\
{$[-2 ; 0]$} & 0.058767 & 0.011551 & -0.002257 & 0.016253 & 0.092056 & 0.089767 & 0.009661 & 0.053503 \\
{$[-1 ; 0]$} & 0.065255 & 0.007617 & 0.002062 & 0.020166 & 0.084624 & 0.088089 & 0.009191 & 0.056705 \\
\hline$\{0\}$ & 0.058056 & $\mathbf{0 . 0 3 9 9 9 7}$ & $\mathbf{0 . 0 0 3 4 8 7}$ & $\mathbf{0 . 0 1 5 6 8 2}$ & $\mathbf{0 . 1 0 5 9 3 4}$ & $\mathbf{0 . 0 9 2 6 7 1}$ & $\mathbf{0 . 0 0 8 6 4 8}$ & $\mathbf{0 . 0 4 1 2 8 9}$ \\
\hline$[-1 ;+1]$ & 0.095472 & 0.010236 & 0.028481 & -0.014920 & 0.076196 & 0.094765 & -0.001695 & 0.104631 \\
{$[-2 ;+2]$} & 0.104211 & 0.007205 & 0.011896 & 0.011648 & 0.030539 & 0.094962 & 0.000273 & 0.106979 \\
{$[-5 ;+5]$} & 0.099513 & -0.024718 & 0.090224 & 0.072158 & 0.046233 & 0.089340 & -0.016507 & 0.090361 \\
{$[-10 ;+10]$} & 0.146329 & -0.090037 & 0.108467 & 0.103425 & 0.101311 & 0.131331 & -0.025409 & 0.212393 \\
{$[-20 ;+20]$} & 0.190369 & -0.015980 & 0.233409 & -0.054654 & 0.026549 & 0.150615 & 0.014812 & 0.210964 \\
\hline
\end{tabular}




\section{Conflicts of Interest}

The authors declare no conflicts of interest regarding the publication of this paper.

\section{References}

Achleitner, A.-K. (2002). Handbuch Investment-Banking (3rd ed.). Wiesbaden, Gabler.

Achleitner, A.-K., Wahl, S., \& Bassen, A (2003). Corporate Restructuring: Instrumente und deren Anwendung in Deutschland. Finanz Betrieb, 7, 432-447.

Barber, B. M., \& Lyon, J. D. (1997). Detecting Long-Run Abnormal Stock Returns: The Empirical Power and Specification of Test Statistics. Journal of Financial Economics, 43, 341-372. https://doi.org/10.1016/S0304-405X(96)00890-2

Bartsch, D. (2005). Unternehmenswertsteigerung durch strategische Desinvestitionen: Eine Ereignisstudie am deutschen Kapitalmarkt. Deutscher Universitäts-Verlag.

Blanton, P., Perrett, A., \& Taino, E. (2000). Unlocking Hidden Value: Realizing Value through Spin-Offs, Carve-Outs, Split-Offs and Tracking Stock. In Equity Research (n.p.). Credit Suisse First Boston.

Bowman, R. G. (1983). Understanding and Conducting Event Studies. Journal of Business Finance \& Accounting, 10, 561-584. https://doi.org/10.1111/j.1468-5957.1983.tb00453.x

Brown, S. J., \& Warner, J. B. (1980). Measuring Security Price Performance. Journal of Financial Economics, 8, 205-258. https://doi.org/10.1016/0304-405X(80)90002-1

Bühner, T. (2004). Unternehmensabspaltungen als Wertsteigerungsinstrument: Eine empirische Untersuchung von Equity Carve-outs und Spin-offs in Europa. Kovač.

Campbell, J. Y., Lo, A. W., \& MacKinlay, A. C. (1997). The Econometrics of Financial Markets. Princeton University Press. https://doi.org/10.1515/9781400830213

Charifzadeh, M. (2002). Corporate Restructuring: Ein wertorientiertes Entscheidungsmodell. Eul.

Fama, E. F. (1970). Efficient Capital Market: A Review of Theory and Empirical Work. The Journal of Finance, 25, 383-417. https://doi.org/10.2307/2325486

Fama, E. F. (1991). Efficient Capital Markets: II. The Journal of Finance, 46, 1575-1617. https://doi.org/10.1111/j.1540-6261.1991.tb04636.x

Fassnacht, A. (2011). Der Reverse Takeover als Alternative zum klassischen Börsengang: Eine empirische Untersuchung europäischer Transaktionen. Universität St. Gallen.

Ganti, A. (2020). Adjusted Closing Price: What Is the Adjusted Closing Price? https://www.investopedia.com/terms/a/adjusted_closing_price.asp

Goerke, B. (2009). Event-Studies. In S. Albers, D. Klapper, U. Konradt, A. Walter, \& J. Wolf (Eds.), Methodik der empirischen Forschung (3rd ed., pp. 467-484). Gabler Verlag. https://doi.org/10.1007/978-3-322-96406-9_30

Grane, H., \& Persson, J. (2018). Shareholder Value Creation through Corporate Spin-Offs. Copenhagen Business School.

Hite, G., \& Owers, J. (1986). The Restructuring of Corporate America: An Overview. In J. M. Stern, \& D. H. Chew (Eds.), The Revolution in Corporate Finance (pp. 418-427). Blackwell.

Interview with Alexander Reimann (2021). Spin-off der Truck \& Bus Sparte der Daimler $A G$.

Jahn, K. (2011). Ereignisstudien: Überblick über die Methode. VDM Verlag Dr. Müller.

Klein, A., \& Rosenfeld, J. (1987). The Influence of Market Conditions on Event-Study Re- 
siduals. The Journal of Financial and Quantitative Analysis, 22, 345-351. https://doi.org/10.2307/2330968

Kumpfmüller, S. (2018). Börseneinführung von Spin-offs. Johannes Kepler Universität Linz.

Lenhard, R. (2009). Erfolgsfaktoren von Mergers \& Acquisitions in der europäischen Telekommunikationsindustrie. Gabler. https://doi.org/10.1007/978-3-8349-8191-2

MacKinlay, A. C. (1997). Event Studies in Economics and Finance. Journal of Economic Literature, 35, 13-39.

May, A. (1991). Zum Stand der empirischen Forschung über Informationsverarbeitung am Aktienmarkt: Ein Überblick. Zeitschrift für betriebswirtschaftliche Forschung, 43, 313-335.

Mazur, M. (2015). Creating M\&A Opportunities through Corporate Spin-Offs. Journal of Applied Corporate Finance, 27, 122-128.

McWilliams, A., \& Siegel, D. (1997). Event Studies in Management Research: Theoretical and Empirical Issues. Academy of Management Journal, 40, 626-657. https://doi.org/10.5465/257056

Möller, H. P. (1985). Die Informationseffizienz des deutschen Aktienmarktes, eine Zusammenfassung und Analyse empirischer Untersuchungen. Zeitschrift für betriebswirtschaftliche Forschung, 37, 500-518.

Ostrowski, O. (2008). Erfolg durch Desinvestitionen: Eine theoretische und empirische Analyse. Deutscher Universitäts-Verlag.

Peterson, P. P. (1989). Event Studies: A Review of Issues and Methodology. Quarterly Journal of Business and Economics, 28, 36-66.

Picken, L. G. (2003). Unternehmensvereinigungen und Shareholder Value. Lang.

Quentmeier, H. (2012). Praxishandbuch Compliance: Grundlagen, Ziele und Praxistipps für Nicht-Juristen. Gabler. https://doi.org/10.1007/978-3-8349-7137-1

Röder, K. (1999). Kurswirkungen von Meldungen deutscher Aktiengesellschaften. Eul.

Rosenfeld, J. (1984). Additional Evidence on the Relation between Divestiture Announcements and Shareholder Wealth. Journal of Finance, 39, 1437-1448.

https://doi.org/10.1111/j.1540-6261.1984.tb04916.x

Serra, A. P. (2002). Event Study Tests: A Brief Survey. Universidade do Porto.

Slovin, M. B., Sushka, M. E., \& Ferraro, S. R. (1995). A Comparison of the Information Conveyed by Equity Carve-Outs, Spin-Offs, and Asset Sell-Offs. Journal of Financial Economics, 37, 89-104. https://doi.org/10.1016/0304-405X(94)00796-4

Stienemann, M. (2003). Wertsteigerung durch Desinvestitionen. Cuvillier.

Strong, N. (1992). Modelling Abnormal Returns: A Review Article. Journal of Business Finance \& Accounting, 19, 533-553. https://doi.org/10.1111/j.1468-5957.1992.tb00643.x

Tagesschau (2021). Daimler spaltet sich auf.

Uddin, M. H. (2010). Corporate Spin-Offs and Shareholders' Value: Evidence from Singapore. The International Journal of Business and Finance Research, 4, 43-58.

van Lelyveld, I., \& Knot, K. (2008). Do Financial Conglomerates Create or Destroy Value? Evidence for the EU. De Nederlandsche Bank NV. https://doi.org/10.2139/ssrn.1208062

Vollmar, J. (2014). Spin-offs, Diversifikation und Shareholder Value: Eine theorie- und hypothesengeleitete empirische Analyse europäischer Unternehmensabspaltungen. Springer Gabler. https://doi.org/10.1007/978-3-658-06559-1 